\title{
Modeling on gas hydrate formation conditions in the Qinghai-Tibet plateau permafrost
}

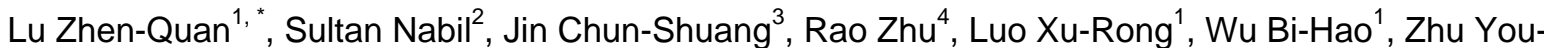 \\ $\mathrm{Hai}^{1}$
}

\footnotetext{
${ }^{1}$ Institute of Mineral Resources, Chinese Academy of Geological Sciences, Beijing 100037, China

2 Département de Géosciences Marines, IFREMER,Centre de Brest, Plouzané 29280, France

${ }^{3}$ Strategic Research Center for Oil and Gas Resources, Ministry of Land and Resources, Beijing 100034, China

${ }^{4}$ National Center for Geological Experiment and Test, Beijing 100037, China
}

*: Corresponding author : Lu Zhen-Quan, email address : luzhq@vip.sina.com

\begin{abstract}
:
Based on the field-investigated gas geochemistry, the modeling of gas hydrate formation conditions is conducted in the Qinghai-Tibet plateau permafrost (QTPP) in combination with predecessors' data such as the permafrost ground temperature (T0), the thermal gradient within the frozen layer (G1) and the thermal gradient below the frozen layer (G2). The modeled results show that the permafrost characteristics generally meet the requirements for gas hydrate formation conditions in the study area. Gas composition, temperature-related permafrost parameters (e.g. T0, G1, G2) are the most important factors affecting gas hydrate formation conditions in the study area, whose spatial variations may cause the heterogeneity of gas hydrate occurrences. The most probable gas composition to form gas hydrate is the hybrid of methane and weight hydrocarbon gases (ethane and propane). In the predicted gas hydrate locations, the minimal upper depth of gas hydrate occurrence is less than one hundred meters and the maximum lower depth can reach one thousand meters with the thickness up to several hundred meters. Compared with Canadian Mallik gas hydrate field, the QTPP is favorable for gas hydrate formation in aspects of $G 1, G 2$ and gas composition, except for relatively thin permafrost, still suggesting great gas hydrate potentials.
\end{abstract}

Keywords: Gas hydrate, Modeling, Formation conditions, Permafrost, Qinghai-Tibet plateau 


\section{INTRODUCTION}

Gas hydrate forms like a solid crystal under low temperature and high pressure conditions with water and light molecule gases such as methane, ethane, propane, hydrogen sulfide, carbon dioxide when they are in excess of their solubility in water, which is generally stable at temperature of 273.15 to $283.15 \mathrm{~K}$ and pressure of 3 to $5 \mathrm{MPa}$. In nature, gas hydrate occurs both in marine subsurface sediment with water depth of greater than 300 meters and in permafrost zone below subsurface depth of more than 130 meters[1]. Because of its huge energy potential, gas hydrate is thought of as an alternative fuel in recent 30 years and due to its possible effects on global carbon circle and subsurface sediment stability after its dissociation, gas hydrate is becoming one hot spot field of investigation and research. As far as China is concerned, it is not until mid to late 1990s that scientists start with the investigation and research on gas hydrate, mainly focusing on offshore China, especially in the northern continental slope of the South China Sea[2 4]. In 2007, in the Shenhu area of the northern South China Sea, a special drilling for gas hydrate project is carried out and gas hydrate samples are obtained, making a great breakthrough in research and investigation of gas hydrate in China[5]. Comparatively, the Qinghai-Tibet plateau permafrost (QTPP) is far from beginning with research and investigation on gas hydrate. Actually as a "third pole in the world", the QTPP with an area of about $1.5 \times 106 \mathrm{~km} 2$, accounting for $70 \%$ and $7 \%$ of the total permafrost in China and in the world respectively[6], is generally regarded as an important potential area for gas hydrate. In reality, breakthroughs in permafrost gas hydrate exploration have already been made abroad and the gas hydrate potentials show a good perspective of exploitation. For example, the 
former Soviet discovered its permafrost gas hydrate in the course of developing the Messoyakha gas field in the western Siberia in 1965 and subsequently obtained a success in exploiting gases from gas hydrate ${ }^{[7 \sim 8]}$. The discovery of the permafrost gas hydrate in the North Slope of Alaska which is revealed by drilling, is another example; scientists estimate that gases from this kind of gas hydrates may be 1.0 to $1.2 \times 10^{12} \mathrm{~m}^{3}$ in volume based on well-log data $^{[9 \sim 11]}$. In the Mackenzie delta permafrost, a series of gas hydrate research wells such as Mallik L-38、2L-38、 $3 \mathrm{~L}-38 、 4 \mathrm{~L}-38 、 5 \mathrm{~L}-38$ are drilled and production of gas hydrate is also tested $\mathrm{d}^{[12 \sim 13]}$.

Therefore in recent years, the QTPP attracts an interest in research and investigation of gas hydrate. Initial results show that the QTPP is not only suitable for gas hydrate growth from the point of view of permafrost characteristics and its gas supply ${ }^{[14 \sim 19]}$, but is also indicated by geophysical and geochemical anomalies ${ }^{[20 \sim 23]}$. However, limited by the extent of investigation and research, the anomalies are locally distributed, which can not demonstrate the whole possible gas hydrate distribution in the permafrost. Hence the general gas hydrate potentials are not yet known.

Chen et al. ${ }^{[24]}$ ever carried out the prediction of gas hydrate occurrences and its volume in the study area just based on of the neighboring gas composition of the Sebei gas filed in the Qaidam basin and the Kela-2 gas field in the Tarim basin. Actually differences in gas composition inevitably exist between the Qaidam basin, the Tarim basin and the QHPP; thus the gas composition of their referred gas fields can not be fully representative of the study area. More over, the hydrocarbon gas composition is not only an important factor affecting gas hydrate formation conditions besides temperature and pressure, but it is also a decisive element for gas hydrate content ${ }^{[25]}$.

Accordingly in this paper, the field-investigated gas geochemistry is based and then an empirical expression for gas hydrate formation conditions is put forward in the QTPP from the point of view of chemical and physical conditions for gas hydrate growth together with predecessors' data such as the permafrost ground temperature $\left(T_{0}\right)$, the thermal gradient within the frozen layer $\left(G_{l}\right)$, the thermal gradient below the frozen layer $\left(G_{2}\right)$; finally its formation conditions are modeled in the study area. The aim, on the one hand, is to discuss how much the gas composition affects possible gas hydrate occurrences in the QTPP by comparing the modeled results based on the investigated gas composition and the predecessor's calculated results based on the neighboring gas field's data; on the other hand, it is also to preliminarily study the possible gas hydrate distribution pattern in the study area.

\section{REGIONAL GEOLOGY AND BACKGROUND OF GAS HYDRATE}

\section{FORMATION CONDITIONS}

\subsection{Regional Geology}

The QTPP mainly extends from the northern slope of the Kunlun Mt. to the northward Anduo County, the southern slope of the Tanggula Mt., which spans about $550 \mathrm{~km}$ along the Qinghai-Tibet railway $(\mathrm{QTR})^{[6]}$, where a series of Mesozoic-Cenozoic remnant basins such as the Kekexili basin, the Tuotuo River basin, the Qiangtang basin, the Tanggula basin. Among them, the Qiangtang basin is largest with thick sedimentary rocks and plentiful organic matter, even with oil \& gas indications or industrial discoveries, which probably provides the study area with enough gases for the gas hydrate growth ${ }^{[18]}$. From the point of view of tectonics, these basins are developed with the multi-staged pulsant but sharp and large-scaled uplifting of the Qinghai-Tibet plateau (QTP). Due to the tectonic evolution in the course of the QTP's uplifting, on the one hand, the reconstruction may forms subsequent structural traps, making oil \& gas accumulated; on the other hand, the tectonic movements are too strong and the extents of uplifting and incision are too intensive, which plays a destructive role in trapping oil \& gas, making light hydrocarbon gases escape rather than be retained. This kind of redistribution of hydrocarbon gases, caused by tectonic devastation, was obvious since Pliocene and Pleistocene. In Pliocene and Pleistocene, the climate was globally and strongly cooling down generally indicated by the oxygen isotope from deep sea foraminifers. In Late Pleistocene and Holocene (about $0.71 M a$ b.p.), the QTP was generally under cryogenic circumstance, causing to 
form a large frozen and mountainous glacier, whose total area is more than $5 \times 10^{5} \mathrm{~km}^{2}$. Except for summer, the stably accumulative snow and the large-scaled glacier enhance the surface reflectivity and increase the winter's freezing high pressure, which further induces coldness in the QTP. At the end of Late Pleistocene, it was within the last maximum glacial period, when the QTP was on the freezing-arid ice frontier, under which the plateau began to form the permafrost in large area. When entering into Holocene, although the large-scaled glaciation was finished, the whole QTP was still under gradual uplifting and its altitude rose to more than 4000 meters, of which the peculiar highness guaranteed that the whole plateau was still on the glacial margin ${ }^{[26]}$. The temperature's fall during Pliocene and Pleistocene, especially the glaciation during Late Pleistocene to Holocene, provided a coupling mechanism for hydrocarbon gases escaped from the tectonically devastated oil \& gas reservoir to be further trapped in the corresponding period; namely the escaped hydrocarbon gases are embraced again to form gas hydrate under low temperature and high pressure conditions (within the permafrost).

\subsection{Background of Gas Hydrate Formation Conditions}

In the permafrost, the formation of gas hydrate is decided mainly by two factors: gas composition and permafrost characteristics. Predecessors ever carried out some gas geochemical investigation and research in the QTPP along the $\mathrm{QTR}^{[21 \sim 22]}$, whose work is to sample the upper 0.5 meters' permafrost and analyze the hydrocarbon gases acid-degassed from sediments (557 samples) with results of $529.05 \mu L$ methane, $22.53 \mu L$ ethane and $12.28 \mu L$ propane out of per $\mathrm{kg}$ sediment on the average. This kind of gas composition is expressed as: $93.83 \% \mathrm{CH}_{4}+3.99 \%$ $\mathrm{C}_{2} \mathrm{H}_{6}+2.18 \% \mathrm{C}_{3} \mathrm{H}_{8}$. Obviously it just reflects the gas composition locally rather than that of the whole study area for possible gas hydrates.

In contrast we investigated the hydrocarbon gases from the mediums of low atmosphere, cold vent, subsurface ice, subsurface sediment in the QTPP along the QTR. The analyzed results show that gases from subsurface sediment are composed of $91.13 \% \mathrm{CH}_{4}+6.54 \% \mathrm{C}_{2} \mathrm{H}_{6}+2.33 \% \mathrm{C}_{3} \mathrm{H}_{8}$; gases from subsurface ice are $96.38 \% \mathrm{CH}_{4}+2.93 \%$ $\mathrm{C}_{2} \mathrm{H}_{6}+0.69 \% \mathrm{C}_{3} \mathrm{H}_{8}$; gases from cold vent are $100 \% \mathrm{CH}_{4}$ or $99.20 \% \mathrm{CH}_{4}+0.80 \% \mathrm{C}_{2} \mathrm{H}_{6}$; gases from low atmosphere are $100 \% \mathrm{CH}_{4}$ on the average ${ }^{[23]}$.

It is seen that the investigated gases from subsurface ice and subsurface sediment are generally similar to predecessors' acid-degassed hydrocarbon gases, whereas the investigated gases from cold vent and low atmosphere differ largely from predecessors' results. In consideration of possible genetic relations of gases from low atmosphere and cold vent to those from subsurface ice, subsurface sediment and acid-degassed hydrocarbon gases, it is not difficult to understand their similarity or difference.

Our past work, namely the analysis on the gas compositions of gas hydrate, gas vent, subsurface sediment in the northern Gulf of Mexico shows that they are generally similar to each other but the hydrocarbon gases become lighter and lighter from subsurface sediment, gas hydrate to gas vent, so it is speculated that these gases are derived from a common gas seepage system of the deep, and the mass fractionation, associated with the gas migration from the deep seepage system to the seafloor and with the gas hydrate formation, causes their close similarity and gradual variation ${ }^{[27]}$. Although the course of gas hydrate formation in the QTPP is different from that of the typical northern Gulf of Mexico, the gas geochemical evolution is expected to be similar. The past investigated gas geochemical results show that there exist certain amounts of propane and normal butane in the mediums of subsurface sediment and subsurface ice besides methane and ethane in the QTPP along the QTR. According to the variation of gas diffusion rate, the presence of ethane, propane, butane associated with methane basically indicates that gases are not simply originated from in situ organic matter but probably from the deep migration ${ }^{[2]}$, especially the occurrence of butane, indicating the deep seepage and diffusion ${ }^{[2]}$. In the QTPP along the QTR there are developed with a series of active fractures or faults such as those of the Kunlun Mt., Tongtian River, Yanshiping, Xidatan, Budong Spring, Chumar River, Beilu River, Erdaogou Basin Margin, Tuotuo River, etc ${ }^{[30]}$. Especially in the Wudaoliang, northern and southern Kekexili Mt. areas, the active strike-slip faults striking approximate EW to NW cut Triassic due to 
strong tectonic movements in Holocene; the multi-stage structural sandy wedges of Late Pleistocene to Holocene occur at faults ${ }^{[31]}$. In the Fenghuo Mt. area, the proximate EW or NWW-strike fracture system is displaced to the purple-red sandstone of the Fenghuo Mt. group of Lower Tertiary; the tectonic lens are also developed in the fractured zone ${ }^{[32]}$. In the Wuli area, the various-scaled and characterized active faults strike near EW or NWW, part of which obviously cut the lacustrine marlite layer, the clay layer and the permafrost layer of Late Pleistocene ${ }^{[33]}$. These fractural structures make it possible to provide with the subsurface gas migration, which means not only providing the dynamic mechanism but also creating paths for subsurface gas migration; especially their deep incision exerts remarkable control over the movement of underground water, which means that gas-bearing fluids migrate from the deep along fractures to the near surface and even form cold vents ${ }^{[33]}$.

Based on this kind of understanding, two cases of gas composition are taken into consideration in the modeling. One is derived from the average gas composition of subsurface ice $\left(96.38 \% \mathrm{CH}_{4}+2.93 \% \mathrm{C}_{2} \mathrm{H}_{6}+0.69 \% \mathrm{C}_{3} \mathrm{H}_{8}\right)$; the other is from that of cold vent $\left(99.20 \% \mathrm{CH}_{4}+0.80 \% \mathrm{C}_{2} \mathrm{H}_{6}\right)$. The relevant gas composition is listed in Table 1. The first case probably represents the general gas supply for gas hydrate formation in the study area. The second case possibly stands for the local anomalous gas characteristics to form gas hydrate. For example, in the Tuojiu Mt. area, gases from subsurface sediment and subsurface ice are highly concentrated and their composition is $99.95 \% \mathrm{CH}_{4}+$ $0.03 \% \mathrm{C}_{2} \mathrm{H}_{6}+0.02 \% \mathrm{C}_{3} \mathrm{H}_{8}$ and almost $100 \% \mathrm{CH}_{4}$ respectively; in the Kunlun Mt. Pass area, gases from subsurface ice and cold vent are also highly concentrated and they are composed of $98.14 \% \mathrm{CH}_{4}+1.60 \% \mathrm{C}_{2} \mathrm{H}_{6}+0.26 \% \mathrm{C}_{3} \mathrm{H}_{8}$ and about $100 \% \mathrm{CH}_{4}$ respectively ${ }^{[23]}$. These gases generally belong to the second case in composition. Chen et al. ${ }^{[24]}$ choose the average gas composition of the Sebei gas filed in the Qaidam basin and the Kela-2 gas field in the Tarim basin as an example to research into the prediction of gas hydrate formation and distribution in the QTPP; in these two gas fields, methane accounts for $97.71 \%$ and $99.18 \%$ respectively, whose composition, to some extent, is similar to that of the field-based geochemical investigation.

Table 1 Hydrocarbon gas composition in various media within the study area and the designated value for this modeling

\begin{tabular}{ccccc}
\hline \multirow{2}{*}{ Medium } & \multicolumn{4}{c}{ Hydrocarbon gas composition /\% Reference } \\
& $\mathrm{CH}_{4}$ & $\mathrm{C}_{2} \mathrm{H}_{6}$ & $\mathrm{C}_{3} \mathrm{H}_{8}$ & \\
\hline subsurface sediment & 93.83 & 3.99 & 2.18 & {$[21,22]$} \\
subsurface sediment & 91.13 & 6.54 & 2.33 & \\
subsurface ice & 96.38 & 2.93 & 0.69 & \\
cold vent & 99.20 & 0.80 & - & {$[23]$} \\
low atmosphere & 100.00 & - & - & \\
possible gas hydrate & 100.00 & - & - & \\
& 96.38 & 2.93 & 0.69 & \multirow{2}{*}{ this paper } \\
\hline
\end{tabular}

Of course, whether gas hydrate can be formed is still dependent on the permafrost characteristics besides gas composition in the study area. Due to the seasonal effect, the superficial thawing happens to a certain depth in the QTPP, but its maximal seasonal thawing depth is relatively small (e.g. the thickness of the QTPP $(D)$ is generally several tens to more than one hundred meters and the thawing depth is just one or two meters $)^{[6]}$. Hence it is assumed that the superficial thawing is negligible for the whole permafrost.

According to the data from scientists of the Lanzhou Institute of Glacier and Geocryology, CAS, the annual average of $T_{0}$ is around -1 to $-3{ }^{\circ} \mathrm{C}$ in the QTPP; $D$ reaches 50 120, 60 120, 80 120 $\mathrm{m}$ in the Kunlun Mt., hilly plateau and Tagula Mt. areas respectively ${ }^{[6]}$. The field measurements show that $D$ is $10 \sim 175 \mathrm{~m}^{[15]}$. Calculated by the empirical relation of $D$ to latitude and altitude, $D$ amounts up to $700 \mathrm{~m}^{[34]} . G_{1}, G_{2}$ are generally about 0.01 , $0.025 \sim 0.03{ }^{\circ} \mathrm{C} / \mathrm{m}$ in the QTPP ${ }^{[6]}$. Zhang et al..$^{[15]}$ point out that $G_{1}, G_{2}$ are $0.011 \sim 0.033$ and $0.028 \sim 0.051{ }^{\circ} \mathrm{C} / m$. Xu et al. ${ }^{[14]}$ refer these values to $0.011 \sim 0.013$ and $0.028 \sim 0.051{ }^{\circ} \mathrm{C} / \mathrm{m}$. In this modeling, median values of $-2{ }^{\circ} \mathrm{C}, 0.0175$ and $0.0333{ }^{\circ} \mathrm{C} / \mathrm{m}$ are given to $T_{0}, G_{l}, G_{2}$ respectively. The given value of $G_{l}$ is very close to that of the present Qingtang 
basin $\left(0.015 \sim 0.018{ }^{\circ} \mathrm{C} / \mathrm{m}\right)^{[35]}$. $D$ is closely related to $T_{0}, G_{l}$ and is calculated by their relationship; for example when $G_{l}$ is given to be $0.0175{ }^{\circ} \mathrm{C} / \mathrm{m}, \mathrm{D}$ is about $120 \mathrm{~m}$ with $T_{0}$ of $-2.10{ }^{\circ} \mathrm{C}$ and about $175 \mathrm{~m}$ with that of $-3.05{ }^{\circ} \mathrm{C}$.

\section{EMPIRICAL MODEL}

Through analyses on variant systems with gas composition, pure / pore water and pore size, the empirical expressions are put forward for predicting gas hydrate formation, and the predicted results are in good agreement with predecessors' experimental data with most variances of less than $5 \%{ }^{[36]}$. This is the base of this modeling. In the QTPP, parameters such as salinity in pore water are not yet know; if referring to the Mackenzie delta, the salinity is very low and just $5 \sim 35 \times 10^{-9[37]}$; such low salinity has little effect on gas hydrate formation conditions and thus can be neglected for the modeling. In the QTPP along the QTR, due to the massive or layered occurrence of subsurface ice, the inhibiting effect of pore size on gas hydrate formation is limited to a small extent and the medium can be considered a non-multi-porous system. Therefore, emphases are put on gas composition, temperature, pressure in the modeling of gas hydrate formation conditions in the QTPP.

Thus, based on the two cases of gas composition, gas hydrate formation conditions can be predicted by the following empirical expression ${ }^{[36]}$ :

$$
P=\left\{\begin{array}{cl}
a+b T+c T^{2} & T<273.15 K\left(R^{2}=0.99999\right) \\
\exp (d \exp (e T)) & T \geq 273.15 K \quad\left(R^{2}=0.999\right)
\end{array}\right.
$$

where units of $P, T$ are $k P a$ and $K$ respectively; when gas composition is $96.38 \% \mathrm{CH}_{4}+2.93 \% \mathrm{C}_{2} \mathrm{H}_{6}+0.69 \%$ $\mathrm{C}_{3} \mathrm{H}_{8}$, parameters of $a, b, c, d, e$ are 31879.57405, -272.5307809, 0.5887745117, 0.1245853818, 0.01487345542; when gas composition is $99.20 \% \mathrm{CH}_{4}+0.80 \% \mathrm{C}_{2} \mathrm{H}_{6}$, these parameters are 31539.62631, -281.6419421, $0.6404997557,0.2988228732,0.01195015602$ respectively.

Meanwhile based on the definition of permafrost, the relationship between $T_{0}(K), D(m), G_{l}\left({ }^{\circ} \mathrm{C} / \mathrm{m}\right)$ can be expressed as:

$T_{0}+G_{1} D-273.15=0$

At a given depth of $h(m), T$ is then figured out:

$$
T=\left\{\begin{array}{cc}
T_{0}+G_{1} h & (h<D) \\
273.15 & (h=D) \\
G_{2}(h-D)+273.15 & (h>D)
\end{array}\right.
$$

where the unit of $G_{2}$ is ${ }^{\circ} \mathrm{C} / \mathrm{m}$.

Similarly, $P$ is calculated according to the litho-static or hydrostatic pressure ${ }^{[38 \sim 39]}$ :

$$
P=\left\{\begin{array}{cc}
P_{0}+\rho_{1} g h 10^{-3} & (h \leq D) \\
P_{0}+\rho_{1} g D 10^{-3}+\rho_{2} g(h-D) 10^{-3} & (h>D)
\end{array}\right.
$$

where $P_{0}$ is the atmosphere pressure $(101 \mathrm{kPa}) ; g$ is the gravity accelerator $\left(9.81 \mathrm{~m} / \mathrm{s}^{2}\right) ; \rho_{1}$ is the bulk density of the frozen layer, whose experimental value is $1500-2000 \mathrm{~kg} / \mathrm{m}^{3[40 \sim 41]}$ and is referred to $1750 \mathrm{~kg} / \mathrm{m}^{3}$ in the modeling ${ }^{[24]} ; \rho_{2}$ is the fluid density below the frozen layer $\left(1000 \mathrm{~kg} / \mathrm{m}^{3}\right)$.

Based on Equations (2), (3) and (4), they can be combined as follows:

$$
P=\left\{\begin{array}{cc}
\rho_{1} g 10^{-3}\left(T+G_{1} D-273.15\right) / G_{1}+P_{0} & (T \leq 273.15) \\
\rho_{2} g 10^{-3}(T-273.15) / G_{2}+\rho_{1} g D 10^{-3}+P_{0} & (T>273.15)
\end{array}\right.
$$

or 


$$
P=\left\{\begin{array}{cc}
\rho_{1} g 10^{-3}\left(T-T_{0}\right) / G_{1}+P_{0} & (T \leq 273.15) \\
\rho_{2} g 10^{-3}(T-273.15) / G_{2}+\rho_{1} g 10^{-3}\left(273.15-T_{0}\right) / G_{1}+P_{0} & (T>273.15)
\end{array}\right.
$$

It is seen that Equations (1), (5) or (6) jointly determine the upper and lower depths of possible gas hydrate occurrence in the study area.

\section{MODELED RESULTS}

By utilizing these empirical equations, gas hydrate formation conditions can be first characterized in the study area (Figure 1). It is seen from the figure that the starting point of $T_{0}$, lines of $G_{1}, G_{2}$ and the gas hydrate equilibrium curve mutually determine possible gas hydrate occurrences. The intersection between the line of $G_{l}$ and the gas hydrate equilibrium curve indicates the upper depth of gas hydrate; the intersection between the line of $G_{2}$ and the gas hydrate phase curve decides the lower depth of gas hydrate; their range is the gas hydrate stability zone.

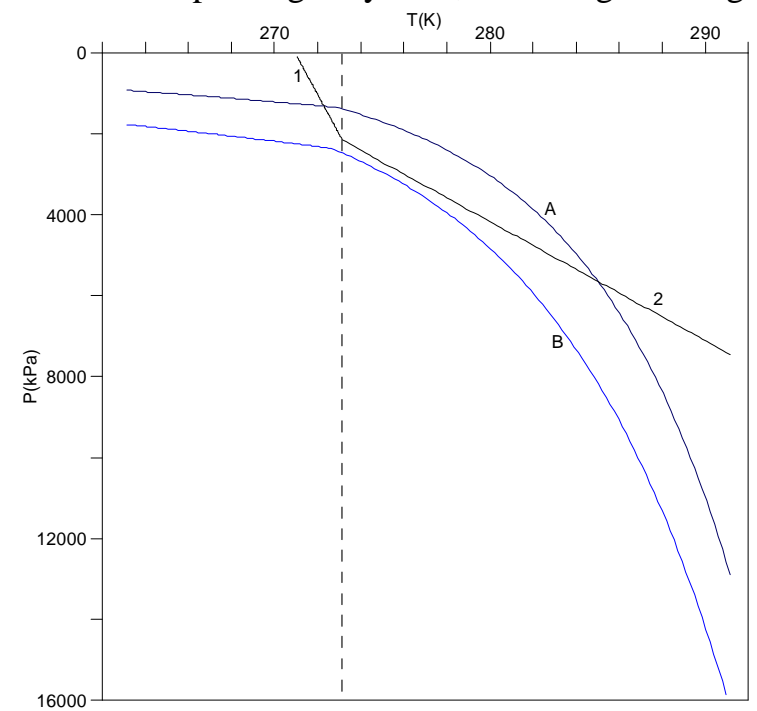

Figure 1 The predictive curve for gas hydrate formation conditions in the study area

Note: 1-the line of $G_{1} ; 2$-the line of $G_{2}$; A-the gas hydrate equilibrium curve when gas composition is $96.38 \% \mathrm{CH}_{4}+2.93 \% \mathrm{C}_{2} \mathrm{H}_{6}+0.69 \% \mathrm{C}_{3} \mathrm{H}_{8} ; \mathrm{B}$-the gas hydrate equilibrium curve when gas composition is $99.20 \% \mathrm{CH}_{4}+0.80 \% \mathrm{C}_{2} \mathrm{H}_{6}$.

Table 2 The modeled results for gas hydrate formation conditions in the study area

\begin{tabular}{|c|c|c|}
\hline \multicolumn{3}{|c|}{ Input of general parameters } \\
\hline$G_{l} /{ }^{\circ} \mathrm{C} \cdot \mathrm{m}^{-1}$ & \multicolumn{2}{|c|}{0.0175} \\
\hline$G_{2} /{ }^{\circ} \mathrm{C} \cdot m^{-1}$ & \multicolumn{2}{|c|}{0.0333} \\
\hline$T_{0} /{ }^{\circ} \mathrm{C}$ & \multicolumn{2}{|c|}{-2.00} \\
\hline$D / m$ & \multicolumn{2}{|c|}{114.29} \\
\hline \multicolumn{3}{|c|}{ Output of computation } \\
\hline Modeled results & Gas composition* & Gas composition** \\
\hline$T_{0}$ maximally for $\mathrm{GH} /{ }^{\circ} \mathrm{C}$ & -0.88 & -2.35 \\
\hline$D$ minimally for $\mathrm{GH} / m$ & 50.57 & 134.41 \\
\hline Predicted upper depth of GH $/ m$ & 71.61 & I \\
\hline Predicted lower depth of GH $/ m$ & 463.67 & l \\
\hline Predicted thickness of $\mathrm{GH} / m$ & 392.06 & l \\
\hline
\end{tabular}

Note: GH-gas hydrate; *-gas composition of $96.38 \% \mathrm{CH}_{4}+2.93 \% \mathrm{C}_{2} \mathrm{H}_{6}+0.69 \% \mathrm{C}_{3} \mathrm{H}_{8} ; * *$-gas composition of $99.20 \% \mathrm{CH}_{4}+0.80 \% \mathrm{C}_{2} \mathrm{H}_{6} ;$ /-no gas hydrates.

It is clear that when gases are composed of $96.38 \% \mathrm{CH}_{4}+2.93 \% \mathrm{C}_{2} \mathrm{H}_{6}+0.69 \% \mathrm{C}_{3} \mathrm{H}_{8}$, it is feasible for gas hydrate to grow; when gases are composed of $99.20 \% \mathrm{CH}_{4}+0.80 \% \mathrm{C}_{2} \mathrm{H}_{6}$, it is difficult to form gas hydrate in the 
study area. Detailed calculations are listed in Table 2. It is shown that the minimal $D$ required for gas hydrate to occur is about $50 \mathrm{~m}$ for the first case of gas composition and about $134 \mathrm{~m}$ for the second case. Actually the calculated $D$ is about $114 \mathrm{~m}$ under the median values for the relevant parameters in the study area. Obviously the second case of gas composition is beyond gas hydrate formation. For the first case, the calculated upper, lower depths and thickness are about 71, 463, $392 \mathrm{~m}$ for possible gas hydrate occurrences.

\section{DISCUSSION AND CONCLUSION}

From the point of view of gas hydrate thermodynamic model, factors of $T, P$, gas composition, pore water's salinity, pore size etc. have varied effects on gas hydrate formation conditions. Quantitative to semi-quantitative analyses show that gas composition, especially mixture of propane has large effects on gas hydrate formation conditions; for example gas hydrate formed from methane mixed with 1, 3,5\% ethane in pure water system needs extra $T$ of $0.40,1.12,1.78{ }^{\circ} \mathrm{C}$ on the average compared with that from pure methane at the same $P$; when methane mixed with 1, 2, 3\% propane in pure water system forms gas hydrate, raising equilibrium $T$ by $2.26,4.13,5.57{ }^{\circ} \mathrm{C}$ separately; salinity in pore water also exerts a certain effect on gas hydrate formation conditions; e.g. methane under proximate sea water system $(31.42 \%$ owt $\mathrm{NaCl})$ forms gas hydrate at $\mathrm{T}$ of $1.5{ }^{\circ} \mathrm{C}$ lower than that under pure water system on the average; pore size at a range of $1 \times 10^{-6} \sim 4 \times 10^{-8} \mathrm{~m}$ has little (negligible) effect on gas hydrate formation conditions; gas hydrate stability is more sensitive to $T$ than to $P$ (e.g. when $T$ increases every $1{ }^{\circ} \mathrm{C}$, the required equilibrium $P$ will rise about 7 atms. $)^{[25]}$.

In the QTPP, the salinity in pore water is not measured; the pore size within a range of $1 \times 10^{-6} \sim 4 \times 10^{-8} \mathrm{~m}$ is very common in most subsurface sediments or rocks; thus besides gas composition, the permafrost characteristics such as $D, T_{0}, G_{1}, G_{2}$ are the most important factors affecting gas hydrate formation in the study area.

In this modeling gas composition comes from the field geochemical investigation. The modeled results are calculated on the bases of the individual median values of $T_{0}, G_{1}$ and $G_{2}$. The results show that gases with the second case of composition can not form gas hydrate in the study area. Certainly variation of $T_{0}, G_{1}$ and $G_{2}$ will directly affect possible gas hydrate occurrences.

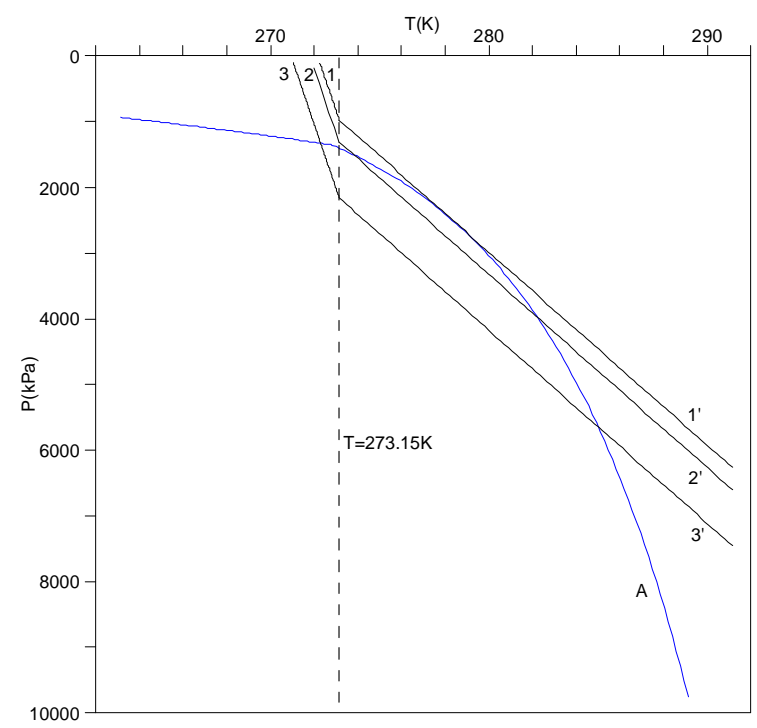

Figure 2 Characterization of possible gas hydrate occurrences

Note: A-the gas hydrate equilibrium curve with gas composition of $96.38 \% \mathrm{CH}_{4}+2.93 \% \mathrm{C}_{2} \mathrm{H}_{6}+0.69 \% \mathrm{C}_{3} \mathrm{H}_{8} ; 1,2,3,1$ ', 2', 3'- the possible lines of $G_{1}, G_{2}$; possible gas hydrate occurrences are controlled by the gas hydrate equilibrium curve and the lines of thermal gradient $G_{l}, G_{2}($ details are given in text).

In theory, possible gas hydrate occurrences are dependent on the relationship between lines of $G_{1}, G_{2}$ and the gas hydrate equilibrium curve. There exist four kinds of their relationship: irrelevant, tangent, cutting and intersecting, 
which correspond to eight possibilities of gas hydrate instances. Theoretical calculations indicate that when $G_{l}$ is individually greater than 0.352 and $0.254{ }^{\circ} \mathrm{C} / \mathrm{m}$ in the two cases of gas composition, the tangent or cutting relationship will take place between the line of $G_{I}$ and the gas hydrate equilibrium curve. Such great values of $G_{I}$ are of no practice in the study area. Thus the possibilities mainly lie in the study area: (1) the irrelevant relationship between the line of $G_{1}$ and the gas hydrate equilibrium curve but the tangent relationship between the line of $G_{2}$ and the gas hydrate equilibrium curve, namely the combination of 1 and 1', in which gas hydrate occurs at the interface; (2) the irrelevant relationship between the line of $G_{l}$ and the gas hydrate equilibrium curve but the cutting relationship between the line of $G_{2}$ and the gas hydrate equilibrium curve, namely the combination of 2 and 2', in which gas hydrate occurs below the frozen layer; (3) the simultaneous intersecting relationship between lines of $G_{l}$, $G_{2}$ and the gas hydrate equilibrium curve, namely the combination of 3 and $3^{\prime}$, in which gas hydrate occurs at a range crossing the base of frozen layer (Figure 2). Calculations suggest that in the two cases of gas composition when $G_{2}$ is separately greater than 0.0652 and $0.0478{ }^{\circ} \mathrm{C} / \mathrm{m}$, gas hydrate occurrences will happen to the instance of (3) at most; when $G_{2}$ is individually no more than 0.0652 and $0.0478{ }^{\circ} \mathrm{C} / \mathrm{m}$, gas hydrate occurrences will happen to the instances of (1), (2) and (3).

Based on the two cases of gas composition, other calculations are also done with the end-member values of $T_{0}, G_{l}$, $G_{2}$ in the study area, and results of possible gas hydrate occurrences are listed in Table 3. It is suggested from the table that some localities can not meet the requirement for gas hydrate formation conditions in the study area. In possible gas hydrate locations, the upper depth of gas hydrate is about 67 to $186 \mathrm{~m}$ and its lower depth is about 244 to $1000 \mathrm{~m}$; the thickness is about 145 to $935 \mathrm{~m}$. Comparatively although the modeled results fall within the range of predictions by Chen et al. ${ }^{[24]}$, they are less exaggerated. Surely the results will be better improved with the further and ongoing investigations.

Table 3 The modeled features of possible gas hydrate occurrences

\begin{tabular}{|c|c|c|c|c|c|c|c|c|}
\hline $\begin{array}{c}\text { Gas } \\
\text { composition }\end{array}$ & $G_{1} /{ }^{\circ} C \cdot m^{-1}$ & $G_{2} /{ }^{\circ} \mathrm{C} \cdot \mathrm{m}^{-1}$ & $T_{0} /{ }^{\circ} \mathrm{C}$ & $D / m$ & $\begin{array}{c}D \text { minimally } \\
\text { for } \mathrm{GH} / m\end{array}$ & $\begin{array}{l}\text { Predicted upper } \\
\text { depth of GH } / m\end{array}$ & depth of GH $/ m$ & $\begin{array}{l}\text { Predicted thickness } \\
\text { of } \mathrm{GH} / \mathrm{m}\end{array}$ \\
\hline \multirow{8}{*}{ case $1^{*}$} & 0.01 & 0.025 & -1.00 & 100.00 & 13.98 & 73.19 & 648.93 & 575.74 \\
\hline & 0.01 & 0.025 & -3.00 & 300.00 & 13.98 & 67.26 & 1002.59 & 935.33 \\
\hline & 0.01 & 0.051 & -1.00 & 100.00 & 72.98 & 73.19 & 244.58 & 171.39 \\
\hline & 0.01 & 0.051 & -3.00 & 300.00 & 72.98 & 67.26 & 585.44 & 518.18 \\
\hline & 0.033 & 0.025 & -1.00 & 30.30 & 13.98 & 186.57 & 447.99 & 261.42 \\
\hline & 0.033 & 0.025 & -3.00 & 90.91 & 13.98 & 71.95 & 628.20 & 556.25 \\
\hline & 0.033 & 0.051 & -1.00 & 30.30 & 72.98 & I & I & / \\
\hline & 0.033 & 0.051 & -3.00 & 90.91 & 72.98 & 71.95 & 217.88 & 145.93 \\
\hline \multirow{8}{*}{ case $2 * *$} & 0.01 & 0.025 & -1.00 & 100.00 & 113.76 & I & I & / \\
\hline & 0.01 & 0.025 & -3.00 & 300.00 & 113.76 & 127.00 & 882.32 & 755.32 \\
\hline & 0.01 & 0.051 & -1.00 & 100.00 & 138.70 & I & I & / \\
\hline & 0.01 & 0.051 & -3.00 & 300.00 & 138.70 & 127.00 & 513.07 & 386.07 \\
\hline & 0.033 & 0.025 & -1.00 & 30.30 & 113.76 & I & I & / \\
\hline & 0.033 & 0.025 & -3.00 & 90.91 & 113.76 & I & I & I \\
\hline & 0.033 & 0.051 & -1.00 & 30.30 & 138.70 & I & I & I \\
\hline & 0.033 & 0.051 & -3.00 & 90.91 & 138.70 & I & I & I \\
\hline
\end{tabular}

Note: GH-gas hydrate; *-gas composition of $96.38 \% \mathrm{CH}_{4}+2.93 \% \mathrm{C}_{2} \mathrm{H}_{6}+0.69 \% \mathrm{C}_{3} \mathrm{H}_{8}$; **-gas composition of $99.20 \% \mathrm{CH}_{4}+0.80 \% \mathrm{C}_{2} \mathrm{H}_{6}$; /- no gas hydrates.

Compared with the world's well-known onshore gas hydrates, the characteristics of $G_{1}, G_{2}$ and gas composition are similar to those of the world's known permafrosts except for its thickness in the QTPP from the point of view of gas hydrate formation conditions, especially the Mackenzie delta area in Canada (Table 4), indicating their comparability. The Mallik gas hydrate field is located on the Mackenzie River delta in the Northwest Territory of 
Canada, close to the margin of the Arctic Ocean, within the northeastern Mackenzie delta, to the south margin of Beufort sea of Beaufort-Mackenzie basin of Arctic Canada. The Beaufort-Mackenzie basin consists of Late Cretaceous to Quaternary, which is situated in the south end of the rifted trough formed by opening of Oceanic Canada basin; since late Cretaceous-Tertiary, the Mackenzie delta area has not experienced any significant tectonic influence, as a result of accumulation of 12 to $16 \mathrm{~km}$ of strata ${ }^{[42 \sim 43]}$. In the Mackenzie delta-Beaufort area, the structural basement is formed by highly faulted Lower Cretaceous, and a regional unconformity separates these strata from 12 to $16 \mathrm{~km}$ of Late Cretaceous to Holocene deltaic, shelf, slope, and deep-water deposits ${ }^{[44]}$. In the Mallik area, eight deltaic sequences are recognized above the Maastrichtian-Palaeocene boundary ${ }^{[43]}$ : (1) Fish River sequence (late Maastrichtian to early Paleocene) including gravity flow deposits composed of conglomerate, sandstone and shale; (2) Reindeer sequence (late Palaeocene-middle Eocene), a suit of widespread thick shale transgression deposits; (3) Richards sequence (late Eocene), shale-dominated strata, representing the continuation of the Reindeer sequence; (4) Kugmallit sequence (early-late Oligocene), which is characterized by an erosional unconformity with the underlying; (5) Mackenzie Bay sequence (late Oligocene-middle Miocene) and (6) Akpad sequence (late Miocene) generally with shale-dominated strata; (7) Iperk sequence (early Pliocene-early Pleistocene), consisting of sandstone and conglomerate; (8) Shallow Bay sequence (Pleistocene-Holocene), almost inseparable from the underlying sequence.

Table 4 Characteristics of the QTPP and other recognized onshore gas hydrates

\begin{tabular}{|c|c|c|c|c|c|c|c|c|c|c|}
\hline Region & $D / m$ & $\begin{array}{c}G_{1} \\
/{ }^{\circ} \mathrm{C} \cdot 100 m^{-1}\end{array}$ & $\begin{array}{c}G_{2} \\
/{ }^{\circ} \mathrm{C} \cdot 100 m^{-1}\end{array}$ & $\begin{array}{c}\mathrm{GH} \\
\text { depth } / \mathrm{m}\end{array}$ & $\begin{array}{c}\text { Gas } \\
\text { composition }\end{array}$ & Gas origin & $\begin{array}{c}\text { Host } \\
\text { lithology }\end{array}$ & $\begin{array}{l}\text { Perspective } \\
\text { volume } / \mathrm{m}^{3}\end{array}$ & $\begin{array}{l}\text { Formation } \\
\text { age }\end{array}$ & Comment \\
\hline $\begin{array}{c}\text { Messoyakha, } \\
\text { Russia }\end{array}$ & 320 & 0.6 & 1.8 & $720 \sim 820$ & $\mathrm{CH}_{4}$ & $\begin{array}{c}\text { hybrid of } \\
\text { thermogenic, } \\
\text { biogenic }\end{array}$ & $\begin{array}{l}\text { sandstone, } \\
\text { shale }\end{array}$ & $(2.6 \sim 2.7) \times 10^{10}$ & $\begin{array}{c}\text { Early } \\
\text { Pleistocene }\end{array}$ & $\begin{array}{l}\text { only the } \\
\text { case of } \\
\text { exploitation }\end{array}$ \\
\hline $\begin{array}{l}\text { Alaska, } \\
\text { U.S.A. }\end{array}$ & $174 \sim 630$ & $1.5 \sim 4.5$ & $1.6 \sim 5.2$ & $0 \sim 950$ & $\begin{array}{c}\mathrm{CH}_{4}, \mathrm{C}_{2} \mathrm{H}_{6}, \\
\mathrm{C}_{3} \mathrm{H}_{8}, \mathrm{~N}_{2}, \\
\text { etc. }\end{array}$ & $\begin{array}{l}\text { hybrid of } \\
\text { biogenic, } \\
\text { thermogenic c }\end{array}$ & $\begin{array}{l}\text { sandstone, } \\
\text { shale, } \\
\text { onglomerate }\end{array}$ & $(1.0 \sim 1.2) \times 10^{12}$ & $\begin{array}{c}{ }_{2} \text { Pliocene to } \\
\text { now }\end{array}$ & $\begin{array}{c}\text { drilling } \\
\text { depth with } \\
666 \mathrm{~m}\end{array}$ \\
\hline $\begin{array}{l}\text { Mackenzie } \\
\text { delta, } \\
\text { Canada }\end{array}$ & $510 \sim 740$ & 1.8 & 2.7 & $890 \sim 1110$ & $\begin{array}{c}\mathrm{CH}_{4}, \mathrm{C}_{3} \mathrm{H}_{8}, \\
\mathrm{CO}_{2}\end{array}$ & therogenic & $\begin{array}{c}\text { sandstone, } \\
\text { shale }\end{array}$ & $1.9 \times 10^{11}$ & $\begin{array}{l}\text { Oligocene } \\
\text { to Pliocene }\end{array}$ & $\begin{array}{c}\text { a test } \\
\text { production } \\
\text { well }\end{array}$ \\
\hline $\begin{array}{l}\text { QTPP, } \\
\text { China }\end{array}$ & $28 \sim 128.5$ & $1.1 \sim 1.3$ & $2.8 \sim 5.1$ & $67 \sim 1002^{\mathrm{a}}$ & $\begin{array}{c}\mathrm{CH}_{4}, \mathrm{C}_{2} \mathrm{H}_{6}, \\
\mathrm{C}_{3} \mathrm{H}_{8}{ }^{\mathrm{b}}\end{array}$ & thermogenic ${ }^{c}$ & unknown & $\begin{array}{c}1.2 \times 10^{11} \sim 2.4 \\
\times 10^{14}\end{array}$ & unknown i & $\begin{array}{c}\text { low } \\
\text { investigation } \\
\text { degree }\end{array}$ \\
\hline
\end{tabular}

Note: GH-gas hydrate; a-modeled results in this paper; b, c-speculations from this work; other data are mainly from ${ }^{[6,14 \sim 16,24]}$.

In the Mackenzie delta area, many oil \& gas fields have been discovered since 1960s, which constitutes an important oil \& gas bearing basin in Canada. It is also a well-known onshore gas hydrate field in the world, where several layers of gas hydrate are encountered and sampled from the Mallik 2L-38 and 5L-38 production and research wells. At the Mallik 2L-38 well, the upper 1150 meters of Oligocene to Holocene sediments are penetrated, of which the cover of upper $640 \mathrm{~m}$ is permafrost; analyses on cores and logging data indicate that there exist five major gas hydrate-bearing layers with the thickness of about $113 \mathrm{~m}$ between 897.25 and $1109.8 \mathrm{~m}$; in situ visual observations recognize gas hydrates predominantly in coarse-grained sandy layers with low-concentrated gas hydrates in fine-grained silty sediments, and rare gas hydrates in thin veins, clasts or nodules, indicating a strong lithological control; they are mainly distributed in unconsolidated to weakly cemented sediments of the Kugmallit, Mackenzie Bay, and Ipek sequences; at the base of gas hydrate zone, the log data suggest that there exists a thin free gas bearing layer (1108.4 to $1109.8 \mathrm{~m})^{[42 \sim 44]}$. Based on P- and S-wave velocities from vertical seismic profiles (VSP) and well logging, calculated results show that at the Mallik 2L-38 well the maximal gas hydrate concentration amounts to $75 \%$ within the interval of 897 to $1110 \mathrm{~m}$ (excluding non-gas hydrate intervals); their averages are 37, 
$21 \%$ from VSP-based calculations respectively and 60, 50\% from well-log calculations respectively ${ }^{[45]}$.

The Mallik 5L-38 gas hydrate production and research well is several hundred meters away from the Mallik 2L-38 well, situated on the downthrown plane of the E-W trending normal fault at the crest of the NW-SE trending Mallik anticline, where the upper sediments $(0$ to $650 \mathrm{~m})$ are permafrost; at this site, sediments cored from the lower to the upper are: the upper Kugmallit sequence of Oligocene (932.64-1150.79 m) and the lower Mackenzie Bay sequence of Late Oligocene to Miocene $(885.63-932.64 \mathrm{~m})$, where three gas hydrate intervals are identified (892-930 $\mathrm{m}$, 942-993 $\mathrm{m}$, 1070-1107 $\mathrm{m}$ ), among which the Mackenzie Bay sequence consists mostly of unconsolidated, well sorted silt to sand beds and pebble interbeds, deposited in a shallow shelf to prodelta environment while the Kugmallit sequence is composed of fluvial / interdistributary channel sands and overbank / floodplain silts and coals, suggesting a consistent floodplain / delta plain environment; gas hydrate is primarily observed in the pores of sandy layers with saturation up to $90 \%$ and nodular or discrete gas hydrate clasts are rarely observed $^{[42 \sim 43]}$. According to the preliminary calculation, the Mallik gas hydrate field including sites of Mallik L-38, 2L-38, 3L-38, 4L-38, 5L-38 holds $2.93 \times 10^{9}$ to $4.15 \times 10^{9} \mathrm{~m}^{3}$ gas at standard conditions within the crest of a large anticlinal feature of $1 \mathrm{~km}^{2[44]}$.

In contrast the Qinghai-Tibet plateau permafrost contains a series of Mesozoic-Cenozoic remnant basins such as the Kekexili, Tuotuo River, Qiangtang and Tanggula basins, in which oil \& gas indications or industrial oils are discovered. In Late Pleistocene to Holocene (about $0.71 \mathrm{Ma}$ b.p.), the QTP was wholly cryogenic, under which a large frozen area formed and a large-scaled mountain glacier occurred; especially at the end of Late Pleistocene, it was in the last maximum glacial period, when the QTP was in the freezing arid ice-margin environment, under which the plateau formed a large-scaled permafrost. After entering into Holocene, the whole QTP arrived at the altitude of greater than 4000 meters, which in return determines the whole plateau was still on the glacial margin ${ }^{[26]}$. The temperature-falling environment during Pliocene to Pleistocene, especially the glaciation during Late Pleistocene to Holocene, provided an opportunity for hydrocarbon gases escaped from oil \& gas reservoir devastated by the synchronous tectonics to be further trapped to form gas hydrate. Peculiarly the characteristics of world-known permafrosts suggest that gas hydrate may occur within the frozen layer as well as below the frozen layer; for example the Messoyakha gas hydrate field, Russia occurs at the depth of 250 350 $\mathrm{m}$ below its frozen layer ${ }^{[1]}$, and the similar case happens to the Mallik gas hydrate field in Canada, which probably indirectly indicates there are also great potentials of gas hydrate in the QTPP.

\section{Acknowledgement}

The initial manual is viewed with constructive suggestions by research professor Chen Duofu and Dr. Song Haibin, respectively from Guangzhou Insitute of Geochemistry and Institute of Geology and Geophysics of Chinese Academy of Sciences. This work is financed by state key basic research and development project "basic study on gas hydrate accumulation laws and exploitation in the South China Sea (2009CB219501)", and projects "study of modelling technology on gas hydrate formation conditions over the QTPP", "investigation and study of gas hydrate potentials over the permafrost around China".

\section{References}

[1] Shi D, Zheng J W. The status and prospects of research and exploitation of natural gas hydrate in the world. Advance in Earth Sciences (in Chinese), 1999, 14 (4): 330 339

[2] Song H B. Geophysical research on gas hydrate. Oceanographic Publishing House (in Chinese), 2003, 1 174

[3] Wu S G, Zhang G X, Guo C S, et al. Geological constraint on the distribution of gas hydrate in the Dongsha continental slope of South China Sea. Acta Petrolei Sinica (in Chinese), 2004, 25 (4): 7 12

[4] Lu Z Q, Wu B H, Zhu Y H, et al., 2006. Geochemical indications of possible gas hydrates in the northeastern South China Sea. Acta Geologica Sinica, 80 (4): 564 573 
[5] Wu N Y, Zhang H Q, Yang S X, et al. Preliminary discussion on natural gas hydrate reservoir system of Shenhu area, North slope of South China Sea. Natural Gas Industry (in Chinese), 2007, 27 (9): 1 6

[6] Zhou Y W, Guo D X, Qiu G Q, et al. Geocryology in China. Scientific Publishing House (in Chinese), 2000, 329 353

[7] Yakushev V S, Chuvilin E M. Natural gas and gas hydrate accumulations within permafrost in Russia. Cold Regions Science and Technology, 2000, 31: 189 197

[8] Collett T S, Ginburg G D. Gas hydrates in the Messoyakha gas field of the west Siberian basin: an extermination of the geologic evidence. Proceedings of 7th International Offshore and Polar Engineering Conference, 1997, 96 103

[9] Collett T S, Kvenvolden K A, Magoon L B. Characterization of hydrocarbon gas within the stratigraphic interval of gas-hydrate stability on the North Slope of Alaska, U.S.A. Applied Geochemistry, 1990, 5 (3): 279 287

[10] Collett T S. Natural gas hydrates of the Prudhoe Bay and Kuparuk River area, North Slope, Alaska. Am. Assoc. Petrol. Geol. Bull., 1993, 77 (5): 793 815

[11] Kamath A, Godbole S P, Ostermann R D, et al. Evaluation of the stability of gas hydrates in Northern Alaska. Cold Regions Science and Technology, 1987, 14 (2): 107 119

[12] Dallimore S R, Uchida T, Collett T S. Scientific results from JAPEX/JNOC/GSC Mallik 2L-38 gas hydrate research well, Mackenzie delta, Northwest Territories, Canada. Geological Survey of Canada, Bulletin, 544, 1999

[13] Dallimore S R, Collett T S. Scientific results from the Mallik 2002 gas hydrate production research well program, Mackenzie delta, Northwest Territories, Canada. Geological Survey of Canada, Bulletin, 585, 2005

[14] Xu X Z, Cheng G D, Yu Q H. Research prospect and suggestions of gas hydrates in permafrost regions on the Qinghai-Tibet plateau. Advance in Earth Sciences (in Chinese), 1999, 14 (2): 201 204

[15] Zhang L X, Xu X Z, Ma W. The Qinghai-Tibet plateau permafrost and gas hydrate. Natural Gas Geoscience (in Chinese), 12 (1): $22 \sim 26$

[16] Wu Q B, Jiang G L, Pu Y B, et al. Relationship between permafrost and gas hydrates on Qinghai-Tibet Plateau. Geological Bulletin of China (in Chinese), 2006, 25 (1): 29 33

[17] Huang B, Pan G T, Wang L Q, et al. Prospect evaluation of natural gas hydrate resources on the Qinghai-Tibet plateau. Geological Bulletin of China (in Chinese), 2002, 21 (11): 794 798

[18] Yi H S, Shi Z Q, Liu W J, et al. The potential and prospect of gas hydrates in the Qinghai-Tibet plateau permafrost zone. Geology of Tibet (in Chinese), 2002, 2002 (1): 45 52

[19] $\mathrm{Ku} \mathrm{X} \mathrm{B,} \mathrm{Wu} \mathrm{Q} \mathrm{B,} \mathrm{Jiang} \mathrm{G} \mathrm{L.} \mathrm{Potential} \mathrm{distribution} \mathrm{of} \mathrm{natural} \mathrm{gas} \mathrm{hydrate} \mathrm{in} \mathrm{the} \mathrm{permafrost} \mathrm{regions} \mathrm{of} \mathrm{Qinghai-Tibet} \mathrm{plateau.}$ Natural Gas Geoscience (in Chinese), 2007, 18 (4): 588 592

[20] Liu H S, Han X L. Geophysical recognition and prediction of natural gas hydrates in Qiangtang basin of Tibet. Northwestern Geology (in Chinese), 2004, 37 (4): 33 38

[21] Wu Z C, Lu X B, Wang Z C. Formation and geochemical exploration model of gas hydrate in the perennial frozen soil area, Qinghai-Tibet plateau. Geological Science and Technology Information (in Chinese), 2006, 25 (4): 9 14

[22] Jian R T, Wang Z C. The geochemical characteristics of gas hydrate in the active zone of the Qinghai-Tibet plateau permafrost. Gansu Metallurgy (in Chinese), 2006, 28 (2): 33 35

[23] Lu Z Q, Wu B H, Rao Z, et al. Geological and geochemical anomalies possibly indicating gas hydrate occurrence in the permafrost zone along the Qinghai-Tibet railway. Geological Bulletin of China (in Chinese), 2007, 26 (8): 1029 1040

[24] Chen D F, Wang M C, Xia B. Formation condition and distribution prediction of gas hydrate in Qinghai-Tibet Plateau permafrost. Chinese J. of Geophys. (in Chinese), 2005, 48 (1): 165 172

[25] Lu Z Q, Sultan N, Jin C S, et al. Semi-quantitative analysis of factors affecting gas hydrate formation conditions and gas hydrate fractions. Chinese J. of Geophys. (in Chinese), 2008, 51 (1): 125 132

[26] Shi Y F, Li J J, Li B Y, et al. Uplift of the Qinghai-Xizang (Tibetan) plateau and east Asia environmental change during Late Cenozoic. Acta Geographica Sinica (in Chinese), 1999, 54 (1): 10 20

[27] Lu Z Q, Sultan N, Géli L, et al. Two-dimensional modeling of gas hydrate occurrences in the northern Gulf of Mexico. International Journal of Earth Science, 2008 (in press) 
[28] Lu Z Q, Wu B H, Zhu Y H. Preliminary Discussion on the Origin and Formation of the Potential Gas Hydrates in the South China Sea. Mineral Deposits (in Chinese), 2002, 21 (3): 232 239

[29] Abrams M A. Significance of hydrocarbon seepage relative to petroleum generation and entrapment. Marine and Petroleum Geology, 2005, 22: 457 477

[30] $\mathrm{Wu} \mathrm{Z} \mathrm{H,} \mathrm{Hu} \mathrm{D} \mathrm{G,} \mathrm{Wu} \mathrm{Z} \mathrm{H,} \mathrm{et} \mathrm{al.} \mathrm{Surface} \mathrm{fractures} \mathrm{and} \mathrm{their} \mathrm{hazard} \mathrm{effects} \mathrm{on} \mathrm{engineering} \mathrm{construction} \mathrm{along} \mathrm{the} \mathrm{Golmud-Lhasa}$ railway across the Tibetan Plateau. Geoscience (in Chinese), 2005, 19 (2): 165 175

[31] Wu Z H, Wu Z H, Hu D G, et al. Geological features of active faults in east Hohxil mountains of northern Tibetan Plateau. Earth Science Frontiers (in Chinese), 2003, 10 (4): 583 589

[32] Wu Z H, Wu Z H, Hu D G, et al. Geological features and hazard effects of the Fenghuoshan active fault system of north Tibetan plateau. Geological Science and Technology Information (in Chinese), 2003, 22 (1): 1 6

[33] Wu Z H, Wu Z H, Zhang Y S, et al. Geological features and hazard effects of the Wuli active fault system on the northern Qinghai-Tibet plateau. Geological Bulletin of China (in Chinese), 2003, 22 (6): 437 444

[34] Wu Q B, Shi B, Liu Y Z. Interaction study of permafrost and highway along Qinghai-Xizang highway. Science in China (Ser. D) (in Chinese), 2003, 46: 97 105

[35] Wang X Y, Yun J B, Luo D Q, et al. Discussion on geodynamic evolution and oil-gas prospect of Qiangtang basin. Acta Petrolei Sinica (in Chinese), 1999, 20 (3): 38 42

[36] Lu Z Q, Sultan N. Empirical expressions for gas hydrate stability law, gas hydrate fraction and gas hydrate layer density at temperature 273.15K to 290.15K. Geochemical Journal, 2008, 42(2): 163 175

[37] Collett T S, Dallimore S. Permafrost-related natural gas hydrate. In: Max M D, ed., Natural gas hydrate in oceanic and permafrost environments, Kluwer Academic Publishers, The Netherlands, 2000, 43 60

[38] Song H B, Matsubayashi O, Yang S X, et al. Physical property models of gas hydrate bearing sediments and AVA character of bottom simulating reflector. Chinese J. Geophys. (in Chinese), 2002, 45 (4): 569 579

[39] Song H B, Jiang W W, Zhang W S, et al. Progress on marine geophysical studies of gas hydrates. Progress in Geophysics. (in Chinese), 2002, 17 (2): 224 229

[40] Liu Z L, Li H S, Zhu Y L, et al. A distinguish model for initial and additional micro-damages on frozen soil. Journal of Glaciology and Geocryology (in Chinese), 2002, 24(5): 676 680

[41] Wang C X. Experimental study of mechanical characteristics of silt permafrost. Coal Technology (in Chinese), 2000, 28 (8): 9 12

[42] Tomaru H, Fehn U, Lu Z, et al. 2007. Halogen systematics in the Mallik 5L-38 gas hydrate production research well, Northwest Territories, Canada: implications for the origin of gas hydrates under terrestrial permafrost conditions. Applied Geochemistry, 2007, 22: 656 675

[43] Haberer R M, Mangelsdorf K, Wilkes H, et al. Occurrence and palaeoenvironmental significance of aromatic hydrocarbon biomarkers in Oligocene sediments from the Mallik 5L-38 Gas Hydrate Production Research Well (Canada). Organic Geochemistry, 2006, 37: 519 538

[44] Moridis G J, Collett T S, Dallimore S R, et al. Numerical studies of gas production from several $\mathrm{CH}_{4}$ hydrate zones at the Mallik site, Mackenzie Delta, Canada. Journal of Petroleum Science and Engineering, 2004, 43: 219 238

[45] Carcione J M, Gei D. Gas-hydrate concentration estimated from P- and S-wave velocities at the Mallik 2L-38 research well, Mackenzie Delta, Canada. Journal of Applied Geophysics, 2004, 56: 73 78 